\title{
Factors Influencing Dividend Payout Policy of Firms Listed on the Nigerian Stock Exchange
}

\author{
Rukaiyat Adebusola Yusuf \\ Department of Accounting, Kingston University, London, United Kingdom
}

Received December 24, 2018; Revised September 23, 2019; Accepted October 1, 2019

Copyright $\bigcirc 2019$ by authors, all rights reserved. Authors agree that this article remains permanently open access under the terms of the Creative Commons Attribution License 4.0 International License

\begin{abstract}
Dividend policy decisions in the emerging markets has continued to receive attention lately in academic research due to the differences observed between developed and emerging markets and sparse empirical evidence in this area. This research is directed towards the emerging markets in Africa. It investigates dividend decision in 299 companies listed in Nigeria on Nigerian stock exchange market. This paper compares dividend decisions in the pre-crisis, crisis and post-crisis periods. Six possible determinants of dividend policy was analyzed using correlation and multiple regression analysis for a period of 13 years (2002 to 2014). The companies are segregated into active and dead groups for the purpose of the analysis. This paper contributes to the current body of knowledge by giving more insights to dividend policy in the largest economy in Africa taking account of the financial crisis of 2008. Liquidity and growth opportunities are common predictors in the three periods. Results are in support of agency, pecking order and signalling theories. The predictors in the regression model explains $42 \%$ variability in dividend policy before the crisis in Nigeria but about $20 \%$ during and afterwards.
\end{abstract}

Keywords Dividends, Nigerian Stock Exchange, Financial Crisis, Agency Theory

\section{Introduction}

Dividend policy has continued to receive attention in academic literature from the 1950s till date because in real life it is an important issue for quoted companies. Dividend is the fraction of net earnings paid to shareholders at determined intervals usually quarterly, semi-annually or annually. Managers are left to decide whether or not to pay dividends, when to pay dividends and what pattern should dividend payments follow, these decisions have grave consequences for the business, shareholders and managers and are referred to as dividend policy of a firm. Despite researches by various scholars aimed at solving the puzzle around why companies pay dividends? Why investors prefer dividends? Do dividends affect firm's value? This contentious issue has remained one of the top issues of utmost concern in finance. Lintner (1956), Miller and Modigliani (1961) and Black (1976) were among the first scholars who attempted to answer the pertinent questions on dividend policy. Miller and Modigliani (1958, 1961) found dividend policy not having effect on shareholders wealth if investment policy is held constant with low dividend payment leading to greater retained earnings and vice versa. Conversely, according to Lintner (1956) firms carefully set up their dividend policies.

Furthermore, the puzzle becomes deeper with higher taxation on dividends in the United States compare to capital gains (La Porta, Lopez-De-Silanes, Shleifer and Vishny, 2000). These evidences pose a puzzle. Researches on dividend policy have led to diverse results, from available literature the divergent empirical results on dividend policy studies can be categorized into three major views, the right wing view been conservative asserts increase in firm value with rise in dividend paid. This is based on the notion that dividends can signal company's future prospects and that managers have asymmetric information. The centrist view affirms no changes in firm's value with dividend cut or increase because shareholders buy shares in companies whose dividend policy they prefer while the left wing view been radical asserts decrease in firm value with increase in dividends payments based on differential treatment between dividend and capital gains in taxation (Al-Malkawi 2008, Mehta, 2012).

Researchers in developed countries have developed theories to explain dividend policies but yet there is continued disagreement on the one which best explains dividend policy. Black (1976) tried to find the rationale behind dividend payment by corporations but he could not exactly say why, thus he termed this as the "Dividend puzzle". Do investors prefer dividends because it's the 
return on their risky investments? Could it be a strategy to signal availability of profitable prospects, could companies be enticing investors by paying dividends to attract other investors and consequently increase share value? These pieces still do not fit despite various researches after Black (1976).

Dividend policy of a firm could be affected by a lot of factors, Baker (2009) group these factors by firm and market characteristics. Factors under market characteristics that influence dividends policies of firms' incudes the state of the economy where it operates which could be measured in terms of gross domestic product (GDP), interest rates, the market, taxes and government regulations. The firm characteristics factors commonly found in literature and proven to influence dividend policy in developed countries is the focal point of this paper due to time and words constraints. These factors include size, profitability, leverage, liquidity, business risk, and growth opportunities

Dividend policies of emerging countries have suffered neglect in academic research when compared to that of developed nations. The difference between developed and emerging countries is enormous as they differ in ease of accessing finance, corporate governance structure, business ownership, taxation amongst others; therefore it is expected for dividend policy to differ between developed and emerging countries. According to World Bank classification, Nigeria is a middle income emerging economies; Nigeria operates a mixed economy with GDP of $\$ 573.65$ billion. Nigeria is the largest economy in Africa (World Bank, 2015) with South Africa, Egypt, Algeria, Angola and Morocco are directly behind them with GDPs of \$350.08, \$286.44, \$214.08, \$128.56, and \$109.20 billion, others have GDPs of $\$ 73.82$ billion and below according TO INTERNATIONAL MONETARY FUND WORLD ECONOMIC OUTLOOK (2015).

Given the significance of Nigeria in Africa and limited studies conducted in this regard, this paper aims to generate an insight into dividend policy of Nigeria by comparing dividend policies for three periods to include before the financial crisis of 2008 (2002 to 2006), during (2007 to 2009) and thereafter (2010 to 2014), thus add to the current body of knowledge regarding dividend policy of emerging countries which is currently inadequate. The global financial meltdown has presented serious challenges for Africa, exposing the weakness inherent in the functioning of the global economy. It affected Africa both directly and indirectly.

The financial sector was affected directly due to great foreign ownership of banks in Africa, although the effect was minimal since most African banks had little or no investment in sub-prime mortgage market and asset back securities. Most countries in Africa owe huge foreign debt. The depreciation of African currencies against the dollar increased the countries debt service burdens. The risk premium demanded by international capital markets from African countries also increased which led to calling off plans by some African countries e.g. Nigeria, Kenya etc. to raise finance from this market. Despite not been fully integrated into the world market, the MSCI emerging index fell by $23 \%$ see figure 1 , Nigeria was exposed to the contagious effect of the crisis (Adamu 2009, Ashamu, and Abiola, 2012).

The financial system and stock market were affected especially banks with foreign credit lines. The effect on the financial sector which was transferred to the real sector made it impossible to exclude Nigeria from countries affected by the meltdown. Nigeria is highly dependent on export of commodities to generate revenue, petroleum is a major commodity exported by Nigeria. Commodity prices suffer a great decline towards the end of 2008 with petroleum prices falling by over 70 percent affecting sustainability of Nigeria's budget (Ashamu, and Abiola, 2012). The sale of Nigeria's oil depends majorly on US and other countries primarily affected by the crisis. US alone account for about $45 \%$ of its revenue from crude oil. Also the country suffered from perpetual fall in stock prices in Nigeria stock market. The decline in Since companies do not operate in isolation of the economy in which liquidity has become a problem, dividends are expected to be adjusted to ensure stability and continued existence post-crisis.
CUMULATIVE INDEX PERFORMANCE - NET RETURNS (USD) (DEC 2000 - NOV 2015)

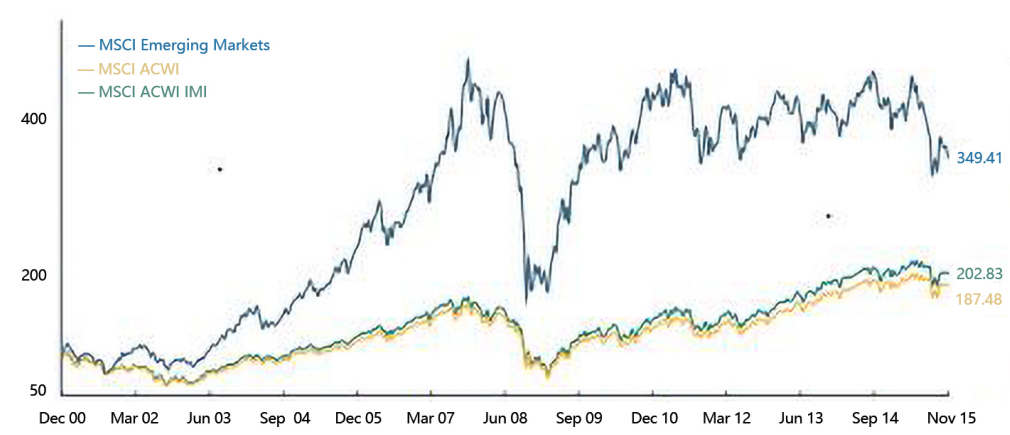

ANNUAL PERFORMANCE (\%)

\begin{tabular}{lrrr} 
Year & $\begin{array}{c}\text { MSCI } \\
\text { merging } \\
\text { Markets }\end{array}$ & MSCI ACWI & MSCI ACWI IMI \\
\hline 2014 & -2.19 & 4.16 & 3.84 \\
2013 & -2.60 & 22.80 & 23.55 \\
2012 & 18.22 & 16.13 & 16.38 \\
2011 & -18.42 & -7.35 & -7.89 \\
2010 & 18.88 & 12.67 & 14.35 \\
2009 & 78.51 & 34.63 & 36.41 \\
2008 & -53.33 & -42.19 & -42.34 \\
2007 & 39.42 & 11.66 & 11.16 \\
2006 & 32.14 & 20.95 & 20.95 \\
2005 & 34.00 & 10.84 & 11.54 \\
2004 & 25.55 & 15.23 & 16.42 \\
2003 & 55.82 & 33.99 & 35.54 \\
2002 & -6.17 & -19.32 & -17.58 \\
2001 & -2.62 & -16.21 & -15.65
\end{tabular}

Source: MSCI emerging market index www.msci.com/resources/factsheets/index_fact_sheet/msci-emerging-markets

Figure 1. MSCI emerging market index 


\section{Literature Review}

Dividends are tied to the financial circumstance of a firm, before considering whether to pay dividends; it is expected for companies to have made profits. Empirical studies have led to conflicting results on factors influencing dividend policies but most studies found firm size and profitability to be positively related with dividend policy while results concerning growth opportunities, business risk, liquidity, and financial leverage are more diverse. AL-Malkawi (2008) explored the determinants of dividend policy of firms in Jordan using probit specification, concluding that factors like size, profitability, growth prospects, leverage and risk that influence dividend decisions in developed markets looks applicable to emerging markets, in aggregate their findings lend support for agency and pecking order theories.

Similarly, Denis, and Osobov (2008) explored the propensity to pay dividends in six countries using logit regression as used by Fama, and French (2001) and concluded that dividend decisions are influenced by firm size, profitability, growth prospects, and equity mix, big and profitable companies are more likely to pay dividends but results on growth prospects are mixed, although dividends paid have reduced, total dividends paid has not. Their findings are consistent with agency cost-based life cycle theory against signalling theory. A study by Fama, and French (2001), found positive relationship between growth opportunities and dividends in contrast with negative relationship found by Patra, Poshakwale, and Ow-Yong (2012), and Botoc, and Pirtea (2014) who examined the behaviour of companies in emerging countries using Ordinary Least Square (OLS) and the Generalized Method of Moments (GMM) and found results similar to(Alli et al. 1993) who took a different approach to re-examine factors that drive dividend policy by carrying out a factorial analysis in addition to multiple regression analysis with evidence in support of most theories including the signalling theory

Mehta (2012) explored the determinants of dividend policy of United Arab Emirates (UAE) companies excluding the financial sector, using correlation and multiple regressions. His findings are in support of profitability and size but liquidity, risk and leverage are found to be unrelated to dividend policy of UAE companies lending support for agency theory. Mehta concluded that a high PE ratio indicates lower risk hence high pay-out. Also highly liquid firms pay fewer dividends. While Patra et al. (2012) who examined the factors influencing dividend policy of non-financial companies listed in Greece employing GMM, found result consistent with Mehta but they found support for liquidity as in Botoc, and Pirtea (2014). They concluded that cash requirement of a company influences dividend. Aivazian et al. (2003) found financial leverage positively related with dividends but Patra et al. (2012) shows inverse relationship. They concluded that highly leveraged companies with high investment prospects may pay lower dividends due to debt covenants against positive evidence by Mehta (2012) for business risk. They concluded that higher leverage and risk comes with higher dividends.

Evident in empirical studies provided above, six determinants that are mostly found in literature and proven to influence dividend policy in developed countries and a few emerging markets is the study's predictors. Mehta (2012) found negative relationship between profitability and dividend decisions concluding that firms will rather invest in its asset instead of paying dividends. Conversely studies by Jensen, Solberg, and Thomas (1992), Fama and French (2001), Aivazian et al. (2003), Al-Malkawi (2008) and Patra et al. (2012), concluded that firm with greater stable earnings are likely to pay more dividends, hence a positive relationship. Does profitability affect dividend policy? This paper hypothesizes a positive relationship between Profitability and dividend policy of firms.

Furthermore, difficulty in accessing external funds from the capital market increases reliance on internally generated funds for smaller companies hence little or no dividends. Conversely larger firms are presumed to pay more dividends since they can access funds from capital markets easily. Studies by Fama and French (2001), Aivazian et al. (2003), Al-Malkawi (2008) Denis and Osobov (2008) and Patra et al. (2012), Mehta (2012) concluded that size is an important factor in dividend decisions with a positive relationship between dividends and firm size. Does size affect dividend pay-out? This paper hypothesize that firm size is positively related to dividend policy. Since it is probable that companies will generate or continue to generate cash flow in the distant future; the anticipated risk of future incomes associated to a company can be implied from $\mathrm{P} / \mathrm{E}$ ratio as high $\mathrm{P} / \mathrm{E}$ suggests higher growth in expected income by investors. Mehta (2012) suggests a negative relationship between risk and dividends, companies with less risk pay high dividends. Can business risk affect dividend pay-out? This paper hypothesizes Business Risk as negatively related to dividend policy of firms.

(Rozeff 1982) suggests that high debt might influence dividend pay-out, due to interest payments, transaction costs or debt covenants companies may pay fewer dividends. This negative relationship was supported by Jensen, Solberg, and Thomas, (1992), Al-Malkawi (2008). Contrarily, positive relationship was found by Kania and Bacon (2005), huge profits are expected of firms that are highly geared and potentially more dividends. Does leverage affect dividends policy? This paper hypothesize that Financial Leverage is negatively related to dividend policy of firms. Since dividends are paid from cash, a company without excess free cash flow is less likely to pay dividend due to its effect on its ability to meet short-term obligation. Therefore, liquidity increases the likelihood to pay dividends Denis and Osobov (2008), and Patra et al. 
(2012). Does liquidity influence dividend payments? This paper hypothesize that Liquidity is positively related to dividend policy of firms.

Finally, Companies at the peak of their growth, with greater investment opportunity have low probability to pay dividends, they will use internally generated funds to finance project consistent with pecking order theory of Myers and Majiluf (1984) thus a negative relationship which was supported by Rozeff (1982), Alli et al. (1993) and Jensen et al. (1992). Conversely firms with declining growth have greater probability of paying dividends Denis and Osobov (2008); does growth prospects influence dividend policy? This paper hypothesize that Growth Opportunity is negatively related to dividend policy of firms.

\section{Theories}

Different theories have been propounded to explain dividend policies by various scholars. Miller and Modigliani's (1961) (M\&M) dividend irrelevance theory was among the first theories explaining dividend policy but it is based on a set of unrealistic assumption, M\&M assumes a perfect market with certainty, without transaction costs and rational investors, and thus concluded that dividend policy is irrelevant as it has no effect on the firm's value. Given the peculiarity of our imperfect market conditions and irrational investors Kania, and Bacon (2005), DeAngelo, and DeAngelo, (2006), dividends are found to be relevant due to the existence of asymmetric information, agency conflicts and problems, transaction costs and preferential treatment of capital gains over dividends for tax purposes. It was this that led to the development of other theories relaxing the assumptions of $\mathrm{M} \& \mathrm{M}$ theory to explain the relevance of dividend policy in practice. Signalling, agency, residual and pecking order theories are contradicting theories to the pioneer dividend irrelevance theory advanced by scholars to solve the debate on dividend decisions and further explain dividend policy in relation to proposed determinants.

Signalling theory implies payments of higher dividend by companies with greater present earnings while companies with lower earnings do otherwise. Increase or decrease in dividend tends to give conflicting results. Scholarly researches have led to results with both negative and positive signals for either increase or decrease in dividends paid. According to Linter (1956), Managers strive to maintain a particular level of dividend payment and unwilling to reduce dividends as changes in dividend policy could be misunderstood thus sending a negative or positive signal leading to fall or rise in share value, this was confirmed by Fama and French (2001). However, the positive signal of dividends have been doubted in a study by DeAngelo, DeAngelo, and Skinner (1996); DeAngelo et al. (2006) and Brav et al. (2005) where they concluded that dividends does not help in identification of companies with greater future profits. It could send negative signals; increasing dividends might mean unavailability of investment opportunities as managers might be overoptimistic over future earnings with decline in growth prospects. Despite the tax disadvantages of dividend and transaction costs, signalling theory indeed explains why most firms still pay dividend.

Agency theory was propounded by Jensen, and Meckling, 1976 with further extension by Rozeff (1982). Agency theory has been prominent and mostly used to explain divided policy after the M\&M theory has been considered irrelevant. When owners are different from manager, agency conflicts thus agency cost could arise, management could engage in projects, acquisitions or expansions that erode shareholders wealth or pay exorbitant salaries and bonus to themselves which are referred to as agency problem. According to the agency theory, agency costs can be minimised by increasing manager's ownership stake in a business thereby aligning the interests of managers and owners Jensen and Meckling (1976). However, this comes with a cost as managers assets becomes less diversified, they will demand more compensation for the increased risk due to increased stake in the firm. Jensen (1986) argued that dividend payments reduced cash at discretion of managers, hence reducing the tendency of investing in value eroding projects and other agency problems as owners could exert control by demanding high dividends.

As regards residual and pecking order theories, firms favour retained earnings for financing new projects against external finance and will only employ external funds in a situation where retained earnings are inadequate to finance projects; thus leading to appreciation of share price and shareholder wealth maximization (Myers, 1984). Dividend decisions are influenced by the availability of profitable positive net present value investment opportunities. Residual theory suggests that management will continue to invest and only pay dividend after all value enhancing projects have been undertaken. Myers (1984); Fama, and French (2001) are advocates of pecking order theory which is similar to residual earnings theory as it also affirms firms preference for retained earnings in financing projects followed by short-term debt with long-term debt as the last resort where retained earnings is insufficient . Myers, and Majluf (1984) opined that firms with high growth prospects have abundant investment needs and are expected to pay fewer dividends. In line with residual theory, residual cash should be given back to shareholders as they can invest in other businesses at their required return and make more profits because keeping such cash within the firm after all positive net present value (NPV) projects have been undertaken will lead to loss of shareholders wealth while raising or paying dividends before undertaking positive NPV projects will lead to loss of value as well (Alli et al. 1993). Studies by Fama, and French (2001) and surveys of 
managers by Baker, Veit, and Powell (2001) and Brav et al. (2005) lend support for pecking order theory.

\section{Study Variables}

The dependent variable of the study is the dividend pay-out ratio. Various measures of dividend pay-out ratio have been found in existing literature to include dividend yield, dividend-to-earnings ratio, and dividend-to-asset ratio. This paper adopts dividend-to-asset ratio in line with Aivazian et al. (2003) and Botoc and Pirtea (2014) to avoid problems that may arise with pricing and volatile earnings when earnings are manipulated to paint a particular picture of the organization using some loopholes in accounting. The independent variables include profitability, firm size, business risk, financial leverage, and liquidity and growth opportunities

\section{Methodology}

This research can be categorised as an explanatory research which tries to explain the causal relationship between variables (Schulz 2003) or an archival research because the research uses publicly available data from archives of companies. Multiple regression and descriptive statistics will be employed consistent with Aivazian et al. (2003), Denis and Osobov (2008) and Mehta (2012) to test each independent variable on the dependent variable and establish the degree of relationship between variables. Multiple regressions will help to measure the relationship between variables, the significance of such relationship and how well each independent variable explains the behavior of the dependent variable. Three regression models will be constructed for each period to enable a comparative analysis of pay-out policies in the three periods.

For accuracy and reliability, test of financial data will be through Statistical Package for Social Sciences (SPSS), a test will be carried out ahead of regression analysis to avoid multi-collinearity effect on each independent variable and increase the reliability and validity of results. If any of the independent variables are highly correlated, it could distort the result of the study, Since there is no exact criterion for evaluating multi-collinearity, judgement based on tolerance value of $<1$ or VIF $>10$ which according to Myers (1990) suggest significant multi-collinearity. To achieve the objectives of this paper, this paper employs the total population of 299 companies listed on stock exchange for 13 years (2002-2014) chosen across all sectors of the Nigerian economy to remove the impact of survivorship bias. On NSE, there are 206 active and 93 dead companies totaled 299.

\section{Results}

The dummy variables $3=$ active companies and $4=$ dead companies respectively, to minimise the effect of outliers in the regression, outliers outside 3 standard deviations are excluded from the analysis. As mentioned earlier a VIF > 10 suggests significant collinearity, Table 1 reports the collinearity test performed in SPSS for each of the period, VIF of all independent variables are $<10$ which implies that the variables are free from potential multicollinearity issues that could distort the results of the study.

From the descriptive statistic in Table 2, the average pay-out ratio of companies active in Nigeria increased during the crisis to $4.10 \%$ but fell after to $3.53 \%$ below $3.61 \%$ pre-crisis which might be attributed to the crisis. Either Nigeria felt the impact at a later stage or Nigerians are reluctant to change pay-out policy. Its standard deviation shows a further movement away from the mean dividend paid by 4.44 before the meltdown to 5.63 and 6.06 during and after respectively. For dead companies average pay-out increased both during and post-crisis with standard deviations showing a further movement away from the mean. Profitability fell during the crisis and increased after with increase in business risk. It also appears that profitability level was affected by the crisis which might explain dividend cut during and after the crisis despite evidence of reluctance to decrease dividends by Linter (1956), Brav et al. (2005). Other variables also show different pattern in movement.

Table 1. Multicolinearity Test

\begin{tabular}{|c|c|c|c|c|c|c|c|}
\hline & & \multicolumn{2}{|c|}{ BEFORE } & \multicolumn{2}{|c|}{ DURING } & \multicolumn{2}{|c|}{ AFTER } \\
\hline STATUS & & Tolerance & VIF & Tolerance & VIF & Tolerance & VIF \\
\hline \multirow[t]{7}{*}{3} & & stant) & & & & & \\
\hline & PB & 0.792 & 1.263 & 0.899 & 1.112 & 0.897 & 1.115 \\
\hline & $\mathrm{BR}$ & & & 0.955 & 1.048 & 0.899 & 1.112 \\
\hline & FL & 0.919 & 1.088 & 0.919 & 1.088 & 0.941 & 1.063 \\
\hline & FS & 0.832 & 1.202 & 0.815 & 1.226 & 0.915 & 1.093 \\
\hline & LT & 0.97 & 1.031 & 0.939 & 1.065 & 0.947 & 1.056 \\
\hline & GO & 0.951 & 1.051 & 0.909 & 1.100 & 0.876 & 1.142 \\
\hline \multirow[t]{2}{*}{4} & & stant) & & & & & \\
\hline & GO & 1.000 & 1.000 & 0.836 & 1.196 & 1.000 & 1.000 \\
\hline
\end{tabular}

Source: SPSS output. 
Table 2. Descriptive Statistics

\begin{tabular}{|c|c|c|c|c|c|c|c|}
\hline & & \multicolumn{2}{|c|}{ BEFORE } & \multicolumn{2}{|c|}{ DURING } & \multicolumn{2}{c|}{ AFTER } \\
\hline STATUS & & $M E A N$ & STD. DEVIATION & MEAN & STD. DEVIATION & MEAN & STD. DEVIATION \\
\hline 3 & DPR & 3.61 & 4.45 & 4.11 & 5.63 & 3.53 & 6.06 \\
\hline & BR & 0.00 & & 17.14 & 26.52 & 16.28 & 13.83 \\
\hline & FL & 2.87 & 4.16 & 7.26 & 32.49 & 2.86 & 5.54 \\
\hline & FS & 90.61 & 90.2 & 81.7 & 79.19 & 74.28 & 65.68 \\
\hline & LT & 0.63 & 0.44 & 0.74 & 0.52 & 0.81 & 0.67 \\
\hline & GO & 28.12 & 29.83 & 41.9 & 54.21 & 13.83 & 18.61 \\
\hline & DPR & 1.19 & 0.82 & 1.8 & 2.62 & 8.29 & 10.23 \\
\hline & PB & .826 .43 & 2328.54 & 744.23 & 2244.18 & 1382.14 & 3374.42 \\
\hline & BR & 0.00 & & 7.17 & 5.89 & 10.68 & 11.93 \\
\hline & FL & 1.91 & 3.75 & 3.27 & 2.62 & -0.46 & 6.76 \\
\hline & FS & 61.42 & 64.71 & 63.25 & 65.52 & 58.36 & 667.11 \\
\hline & LT & 0.54 & 0.55 & 0.57 & 0.61 & 0.55 & \\
\hline
\end{tabular}

Source: SPSS output.

Table 3. Correlation Result

\begin{tabular}{|c|c|c|c|c|c|c|c|}
\hline & & Status & & 3 & Status & 4 \\
\hline & & BEFORE & DURING & AFTER & BEFORE & DURING & AFTER \\
\hline \multirow{3}{*}{ Pearson Correlation } & & DPR & DPR & DPR & DPR & DPR & DPR \\
\cline { 2 - 8 } & DPR & 1.000 & 1.000 & 1.000 & 1.000 & 1.000 & 1.000 \\
\hline & PB & 0.461 & 0.235 & 0.087 & -0.219 & 0.324 & 1.000 \\
\hline & BR & & 0.046 & 0.194 & & 0.913 & \\
\hline & FL & -0.144 & -0.105 & -0.176 & -0.592 & -0.267 & 1.000 \\
\hline & FS & 0.493 & 0.379 & 0.38 & 0.67 & -0.015 & 1.000 \\
\hline & LT & 0.174 & 0.088 & 0.021 & -1 & -0.751 & \\
\hline & GO & -0.211 & -0.167 & -0.091 & -0.657 & -0.366 & -1.00 \\
\hline & DPR & & & & & & \\
\cline { 2 - 8 } & PB & 0.000 & 0.019 & 0.215 & 0.362 & 0.239 & 0.000 \\
\hline & BR & & 0.366 & 0.049 & & 0.134 & \\
\hline & FL & 0.137 & 0.181 & 0.054 & 0.146 & 0.281 & 0.000 \\
\hline & FS & 0.000 & 0.000 & 0.000 & 0.108 & 0.487 & 0.000 \\
\hline & LT & 0.132 & 0.274 & 0.439 & 0.000 & 0.23 & \\
\hline & GO & 0.071 & 0.081 & 0.204 & 0.171 & 0.238 & 0.000 \\
\hline
\end{tabular}

Source: SPSS output.

The correlation results presented in table 3 shows a positive relationship between dividend policy and profitability, size, and liquidity with financial leverage and growth opportunities negatively related to dividend decisions throughout the periods in view in active companies, increase in each of these variables leads to raise in dividends. Dead companies exhibit same association between growth and dividends with active companies with conflicting result in other variables in the periods. Although business risk was omitted in most of the period analysis due to missing values, it has a positive relationship with dividends where available in both groups Of all variables firm size is most correlated with dividend policy in Nigerian active companies throughout the periods, for dead company's liquidity was paramount before the crisis but risk became more important during with a combination of profitability, leverage, size and growth afterwards

\section{Regression Results}

Table 4 reports the model summary for the periods, $R^{2}$ shows that $43 \%$ of the variability in dividend policy pre-crisis is explained by all the independent variables in the regression model for both dead and active companies in Nigeria. This $R^{2}$ is similar to results by Kania and Bacon (2005), Dada et al. (2015), and Mehta (2012) with 38\%, $39 \%$, and $43 \%$ respectively. During and post-crisis the variability in dividend policy explained by the independent variables decreased to $19 \%$ for active companies with a decrease to $15 \%$ during the crisis for the dead and a surprising rise to $100 \%$ afterwards. This implies that the predictors became less important in explaining dividend policy during the crisis but more important afterwards most especially in the dead companies with $100 \%$. 
Table 4. Model Summary

\begin{tabular}{|c|c|c|c|c|}
\hline & & Before & & \\
\hline & & & Adjusted & Std. Error of \\
\hline Status & Model & R Square & R Square & the Estimate \\
\hline 3 & 1 & 0.429 & 0.351 & 3.58 \\
\hline \multirow[t]{3}{*}{4} & 1 & 0.432 & & \\
\hline & & During & & \\
\hline & & & Adjusted & Std. Error of \\
\hline Status & Model & R Square & R Square & the Estimate \\
\hline 3 & 1 & 0.196 & 0.075 & 5.41 \\
\hline \multirow[t]{3}{*}{4} & 1 & 0.151 & & \\
\hline & & After & & \\
\hline & & & Adjusted & Std. Error of \\
\hline Status & Model & R Square & R Square & the Estimate \\
\hline 3 & 1 & 0.197 & 0.102 & 5.74 \\
\hline 4 & 1 & 1 & & \\
\hline
\end{tabular}

Source: SPSS output.

Table 5. ANOVA

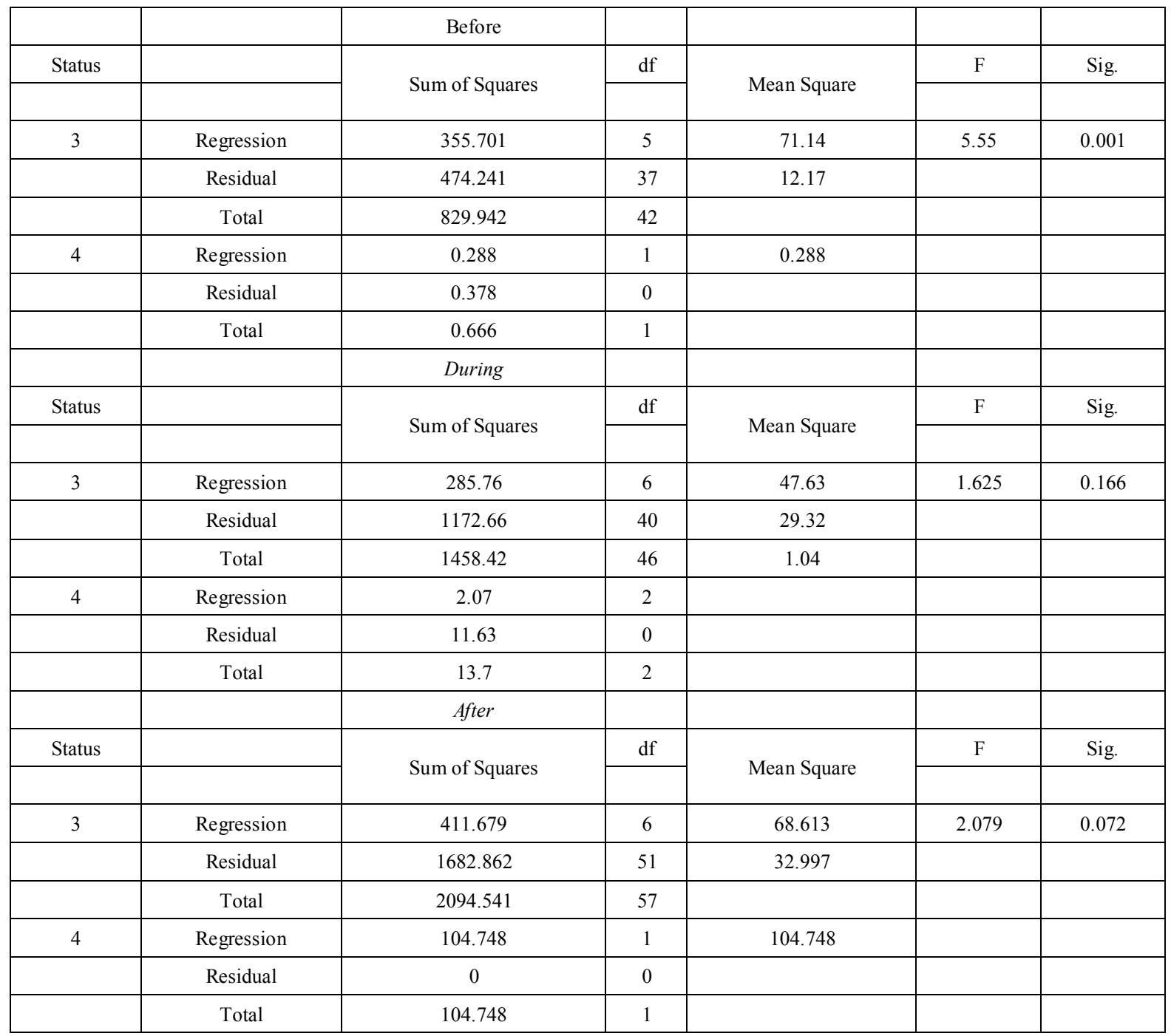


Furthermore, from ANOVA results reported in table 5, the F-statistics proofs that the estimated model is valid despite reduction in F-statistic during and post-crisis with $\mathrm{p}=$ values $>0.05$ making results statistically insignificant. This suggests a stronger relationship between dividend policy and these determinants, emphasizing that these predictors of dividend policy became less relevant during and post-crisis in Nigeria. The significant explanatory strength of the model as determined by the F-statistic is consistent with Kania and Bacon (2005), and Mehta (2012).

Table 6. Coefficient results

\begin{tabular}{|c|c|c|c|c|c|c|c|}
\hline & & & \multicolumn{2}{|c|}{ Unstandardized Coefficients } & \multicolumn{3}{|c|}{ Standardized Coefficients } \\
\hline & Status & & B & Std Error & Beta & $\mathrm{t}$ & Sig. \\
\hline $\mathrm{B}$ & 3 & (Constant) & 1.69 & 1.287 & & & 0.197 \\
\hline $\mathrm{E}$ & & PB & 0.669 & 0.244 & 0.382 & 2.736 & 0.009 \\
\hline $\mathrm{F}$ & & FL & -0.235 & 0.138 & -0.219 & -1.693 & 0.099 \\
\hline $\mathrm{O}$ & & FS & 0.016 & 0.007 & 0.317 & 2.326 & 0.026 \\
\hline $\mathrm{R}$ & & LT & 1.818 & 1.265 & 0.181 & 1.437 & 0.159 \\
\hline \multirow[t]{4}{*}{$\mathrm{E}$} & & GO & -0.023 & 0.019 & -0.157 & -1.229 & 0.227 \\
\hline & 4 & (Constant) & 1.839 & 0.000 & & & \\
\hline & & GO & -0.013 & 0.000 & -0.657 & & \\
\hline & Status & & & & & & \\
\hline $\mathrm{D}$ & 3 & (Constant) & 1.043 & 2.018 & & 0.517 & 0.608 \\
\hline $\mathrm{U}$ & & PB & 0.162 & 0.185 & 0.131 & 0.879 & 0.385 \\
\hline $\mathrm{R}$ & & $\mathrm{BR}$ & 0.015 & 0.031 & 0.072 & 0.496 & 0.622 \\
\hline I & & FL & -0.014 & 0.026 & -0.081 & -0.551 & 0.585 \\
\hline $\mathrm{N}$ & & FS & 0.024 & 0.011 & 0.342 & 2.178 & 0.035 \\
\hline \multirow[t]{7}{*}{ G } & & LT & 1.5 & 1.577 & 0.139 & 0.951 & 0.347 \\
\hline & & GO & -0.007 & 0.015 & -0.07 & -0.468 & 0.643 \\
\hline & 4 & (Constant) & 3.203 & & & & \\
\hline & & FL & -0.142 & 0.000 & -0.142 & & \\
\hline & & GO & -0.026 & 0.000 & -0.309 & & \\
\hline & Status & & & & & & \\
\hline & 3 & (Constant) & 0.479 & 1.939 & & 0.247 & 0.806 \\
\hline A & & PB & 0.051 & 0.09 & 0.075 & 0.566 & 0.574 \\
\hline $\mathrm{F}$ & & BR & 0.049 & 0.058 & 0.111 & 0.838 & 0.406 \\
\hline $\mathrm{T}$ & & $\mathrm{FL}$ & -0.109 & 0.142 & -0.1 & -0.773 & 0.443 \\
\hline $\mathrm{E}$ & & FS & 0.033 & 0.012 & 0.361 & 2.753 & 0.008 \\
\hline \multirow[t]{4}{*}{$\mathrm{R}$} & & LT & 0.725 & 1.172 & 0.08 & 0.619 & 0.539 \\
\hline & & GO & -0.044 & 0.044 & -0.135 & -1.005 & 0.32 \\
\hline & 4 & (Constant) & 25.698 & 0.000 & & & \\
\hline & & GO & -1.415 & 0.000 & & & \\
\hline
\end{tabular}

Source: SPSS output. 
There is a positive relationship between profitability and dividend policy of active companies in Nigeria throughout the periods despite decreasing beta and T-statistics from 0.382 and 2.74 to 0.075 and 0.25 shown in table 6 . This implies payment of dividends by highly profitable firms with less volatile earnings. The statistically significant result with p-value 0.009 before the crisis became insignificant during and after with $p$-values $>0.05$. There is no result for dead companies due to missing values. The positive relationship is consistent with Aivazian et al. (2003), Al-Malkawi (2008), therefore the hypothesis is accepted. This paper hypothesizes a negative insignificant relationship between financial leverage and dividend policy, as expected table 6 confirms it and this hypothesis is accepted. The t-statistics and beta coefficients are negative for active companies. . This it implies that lower dividends are expected of highly geared and risky firms, as debt increases, dividend paid decreases and vice versa. The decrease in beta and t-statistics from -.219, -1.693 to -0.81 , -0.551 implies that high financial leverage decreases the probability of paying dividends most especially during the crisis period with decrease in beta and t-statistics from $-.219,-1.693$ to $-0.81,-0.551$. Results are consistent with Rozeff (1982), Aivazian et al. (2003), Al-Malkawi (2008) and Uwuigbe (2013) but in contrast with Kania and Bacon (2005) who concluded that high leverage comes with high profit and therefore more dividends. No results for dead companies due to missing values.

Furthermore, findings in table 6 shows that firm size is positively associated with dividend policy in Nigerian active companies throughout the three periods in view, evident in beta and t-statistics which is significant with p-values $>0.05$. This is in line with agency theory of Jensen and Meckling (1976). The perception is that the bigger a firm, the costlier its management, hence dividends might help in the reduction of agency problems. This is consistent with Fama and French (2001), Denis and Osobov (2008), Mehta (2012), Patra et al. (2012). Therefore, the hypothesis that firm size is positively related to dividends policy is accepted. As regards liquidity, in table 6 the results as expected show positive association between liquidity and dividend policy although insignificant which is consistent with Patra et al. (2012), Botoc and Pirtea (2014) but in contrast with Dada et al. (2015). Therefore, the hypothesis that liquidity is positively related to dividends is accepted. Contrary to the hypothesis that risk is negatively associated with dividends, result from table shows a positive insignificant relationship between risk and dividend policy in both countries although there is no result before the crisis for active companies and throughout the periods for dead companies due to missing values. This implies payment of huge dividends by risky firms which is contrary to prior studies by Kania and Bacon 2005, Patra et al. (2012) and Mehta (2012).

Finally, Overall results in table 6 shows an insignificant negative relationship between growth and dividend policy consistent with Rozeff (1982), Alli et al. (1993), Patra et al. (2012), Jensen et al. (1992) . This lends supports for pecking order theory which implies payment of fewer dividends by companies with huge growth opportunities. Therefore the hypothesis that Growth Opportunity is negatively related to dividend policy of firms is accepted

\section{Conclusions}

This paper concludes that dividend policy is determined by similar factors for both dead and active companies in these periods. Although there are no results with respect to dead companies due to missing values of some tested variables. As expected, profitability, firm size, and liquidity are positively associated with dividend policy, financial leverage and growth opportunity are negatively related to dividend policy in Nigeria but contrary to expectation business risk is positively associated to dividend policy. This implies increase in dividends with rise in business risk, the riskier a firm the larger its pay-out. This has led to the acceptance of four hypotheses and rejection of the hypothesis on business risk. Pay-out increased during the crisis in Nigeria but fell afterwards, Nigerian companies felt the impact of the crisis later or they want to look stronger and less affected by the crisis among others, or that less growth opportunities during the crisis led to demand for more dividends consistent with agency theory to prevent investment in value eroding projects by managers, or managers might be afraid of cutting dividends so as not to create panic among investors and subsequently lead to fall in share prices. Results are similar to other studies in emerging countries, similar factors influence dividend policy with or without crisis.

\section{Recommendations}

This study's $R^{2}$ is less than $50 \%$ in most period except in dead companies post-crisis, therefore, the incorporation of other factors that could explain most of the variability in dividend policy is recommended in future studies. These could include corporate governance, political, social, economic, and other factors that affect businesses as a whole. Further research could separate and analyse highly regulated companies from others, a comparison of dividend policy as regards the crisis period could be down between countries majorly affected (US,UK) and those with the contagion effect. Corporations should constantly review its dividend policies in a manner that suits companies prevailing conditions and shareholders interest thereby aligning the interests of both parties and maybe reduce agency problems. 


\section{REFERENCES}

[1] Adamu, A. (2009) 'The effect of financial crisis on Nigerian economy', International Journal of Investment and Finance.

[2] Aivazian, V., Booth, L. and Cleary, S. (2003) 'Do emerging market firms follow different dividend policies from U.S firms'? The Journal of Financial Research.

[3] Alli, K.L., Khan, Q.A. and Ramirez, G.G. (1993) 'Determinants of corporate dividend policy: a factorial analysis', The Financial Review.

[4] Al-Malkawi, H.N. (2008) 'Factors influencing corporate dividend decision: evidence from Jordanian panel data', International Journal of Business.

[5] Ashamu, S.O. and Abiola, J. (2012) 'The impact of global financial crisis on Nigerian banking sector in Nigeria', British Journal of Arts and Social Sciences.

[6] Baker, K.H. (2009) Dividends and dividend policy. Wiley, ISBN-13: 9780470455807

[7] Baker, K.H., Veit, T.E. and Powell, G.E. (2001) 'Factors influencing Dividend policy decisions of NASDAQ firms', The Financial Review.

[8] Black, F. (1976) 'The dividend puzzle', The Journal of Portfolio Management.

[9] Botoc, C. and Pirtea, M. (2014) 'Dividend pay-out policy drivers: evidence from emerging countries', Emerging Markets Finance and Trade.

[10] Brav, A., Graham J.R., Harvey C.R. and Michealy, R. (2005) 'Pay-out policy in the $21^{\text {st }}$ century', Journal of financial economics.

[11] Dada F.B., Malomo, E. and Ojerinde, S. (2015) 'Critical evaluation of the determinants of dividend policy of banking sector in Nigeria', International Journal of Economics, Commerce and Management.

[12] DeAngelo, H., DeAngelo, L. and Skinner, D.J. (1996) 'Reversal of fortune: Dividend signalling and the disappearance of sustained earnings growth', Journal of Financial Economics, vol. 40, no. 3, pp. 341.

[13] DeAnegelo, H. and DeAngelo L. (2006) 'The irrelevance of the MM dividend irrelevance theorem', Journal of Financial Economics, vol. 79, no 239-315

[14] Denis, D.J. and Osobov, I. (2008) 'Why do firms pay dividends? International evidence on the determinants of dividend policy', Journal of Financial Economics.

[15] Fama, E.F. and French, R.K. (2001) 'Disappearing dividends: changing firm characteristics or lower propensity to pay'? Journal of Financial Economics.

[16] International Monetary Fund World Economic Outlook (April 2015)

[17] Jensen, M.C. (1986) 'Agency cost of free cash flow, corporate finance, and takeovers', AEA Papers and Proceedings.

[18] Jensen, M.C. and Meckling, W.H. (1976) 'Theory of a firm: managerial behaviour, agency cost and ownership structure', Journal of Financial and Economics.
[19] Jensen, G.R., Solberg, D.P. and Thomas, Z.S. (1992) 'Simultaneous determination of insider ownership, debt and dividend policies', Journal of Financial and Quantitative Analysis.

[20] Kania, S.L. and Bacon, F.W. (2005) 'What factors motivate the corporate dividend decision?’ ASBBS E-Journal.

[21] La Porta, R., Lopez-De-Silanes, F., Shleifer, A. and Vishny, R.W. (2000) 'Agency problems and dividend policies around the world', The Journal of Finance, vol 4.

[22] Lintner, J. (1956) 'Distribution of incomes of corporations among dividends, retained earnings and taxes', American Economic Review, 46: 97-113.

[23] Mehta, A. (2012) 'An empirical analysis of determinants of dividend policy- evidence from UAE companies', Global Review of Accounting and Finance.

[24] Miller, M. and Modigliani, F. (1961) 'Dividend policy, growth, and the valuation of shares', Journal of Business, 34: 411-433

[25] Modigliani, F. and Miller, M. (1958) 'The cost of capital, corporation finance, and the theory of investment', American Economic Review 48, 261-297.

[26] Myers, S.C. (1984) 'The capital structure puzzle', The Journal of Finance.

[27] Myers, S.C. and Majluf, N.S. (1984) 'Corporate financing and investment decisions when firms have information that investors do not have', Journal of Financial Economics.

[28] Myers, R. (1990) 'Classical and Modern regression with application $2^{\text {nd }}$ ed. Boston, MA; Duxbury.

[29] Patra, T., Poshakwale, S. and Ow-Yong, K. (2012) 'Determinants of corporate dividend policy in Greece', Applied Financial Economics.

[30] Rozeff, M.S. (1982) 'Growth, beta and agency costs as determinants of dividend pay-out ratios', The Journal of Financial Research.

[31] Schulz, S. (2003) 'Views on the Combination of Qualitative and Quantitative Research Approaches', Journal of Applied Research.

[32] Uwuigbe, O., A. (2013) 'Determinants of Dividend policy: A study of selected listed firms in Nigeria', Manager Journal.

[33] World Bank (2015), 'Gross domestic product 2014', World Development Indicators database. 